Ivana Đurić Paunović

Faculty of Philosophy

University of Novi Sad

\title{
THE VARIATION IN NON-FINITE COMPLEMENTS IN SERBIAN: EMPIRICAL EVIDENCE AT AN INTRA-SPEAKER LEVEL
}

The paper investigates the nature of syntactic variation in non-finite complements of modal verbs in Serbian. Specifically, we examine what factors may underlie the intra-speaker variation in the choice of infinitive over $d a+$ present, and how these differences can be represented structurally. The empirical data from a restricted corpus study confirm the observation from the literature that infinitive is often used for stylistic reasons and in impersonal contexts. What we have also found is that for the speaker infinitive is preferred with abstract or non-referential subjects, with stative complements and in the context of epistemic rather than deontic modals. We hypothesize that all the grammatical factors converge around the pivotal role of the subject in the two constructions. An account that predicts enough structural similarity between $d a+$ present and infinitive to allow virtual interchangeability, while postulating enough difference in terms of the role of the subject to accommodate the observed differences could, thus, be a good candidate to explain the observed phenomena.

Key words: non-finite complements, $d a+$ present, infinitive, syntactic variation, a translation study

\section{INTRODUCTION}

Syntactic variation, or the question why a language employs two different structures in the seemingly same context, has been a challenge from both theoretical (especially, generative) and descriptive linguistic perspective. If in a given context, no interpretational (semantic, information-structural or pragmatic) differences seem to arise more or less immediately, or more or less obviously, then the two syntactic structures are considered to be in free variation. A language with free variation is often considered to exhibit some type of competing grammars, with two grammatical options being equally available to its speakers (cf. Huddican \&

pedjakovacevic90@gmail.com 
Plunkett, 2010 and all relevant references there). ${ }^{1}$ Variation is thus both a challenge and motivation for theoretical approaches assuming Universal Grammar. ${ }^{2}$

A different option is that variation is only seemingly free, as factors governing one choice over the other are too subtle to be identified as deciding ones.

A case of syntactic variation of interest in this paper is the variation found in the non-finite complements in Serbian between the so-called $d a+$ present and infinitive after modal verbs (1). ${ }^{3}$

$\begin{array}{llll}\text { On mora da } & \text { kupi } & \text { /kupiti } & \text { auto } \\ \text { he must DA } & \text { buy.3S.pres } & \text { /buy.INF } & \text { car } \\ \text { 'He has to buy a car' } & & \end{array}$

The issue of the variation in the use between $d a+$ present and infinitive has been subject of much research on Serbian, both in terms of providing adequate descriptions of the contexts requiring or showing preference for one form over the other, and in terms of the geographical and dialectal distribution of the variation (cf. Piper-Antonić-Ružić-Tanasić-Popović \& Tošović, 2005, and an overview in Belić, 2005).

In this paper we set out to examine further the question of how free the variation between $d a+$ present and infinitive is, to uncover the key factors setting out certain contexts more 'appropriate' for one non-finite form over the other, and ultimately show how these subtle distinctions map onto the syntactic representation.

\footnotetext{
${ }^{1}$ More recent approaches to syntactic variation rather assume the existence of 'variables' in a single grammar, which can have multiple identifiable 'variants' or realizations.

${ }^{2}$ The study of variation is important because (i) only by understanding what can vary can we infer what has to be universal; and (ii) the best way to understand a particular structure is to see what other kinds of structures can stand in its place in different varieties of the language.

${ }^{3}$ Even though the variation is found with other types of verbs, here we are concerned only with the non-finite complements which require a null subject. Note also that the term 'present' here is used only as a formal identification of the verbal form, as it has no present tense interpretation, nor is any other tense form available (cf. Ivić, 1970, among many others).
} 


\section{BACKGROUND}

In the vast literature on the topic, there seems to be a consensus that regional, sociolectal, stylistic, and idiolectal factors play a certain role in the distribution of infinitives and $d a+$ present complements (cf. Ivić, 1972; Piper et al., 2005; Belić, 2005 and references there).

As for purely linguistic differences, lexical factors (the role of the type of lexical verb, mostly the embedded verb (cf. Gallis, 1970; Piper et al., 2005, a.o.), but also the matrix one (negated modal hteti 'want' vs. future auxiliary, impersonal predicates, imperative-cohortative hajde 'let's') are argued to be significant. Impersonal predicates have been systematically shown to prefer infinitives, or even require them, in cases of covert modality (cf, Piper et al., 2005; Belić, 2005; Ajdžanović \& Dražić, 2016, a.o.). Belić (2005) bases his semantic account of the variation on the impersonal adjectival predicates, claiming that the referential argument in the matrix part makes $d a+$ present preferable due to the nature of the null subject found there. ${ }^{4}$ A semantic account can be also be found in Ivić, 1970, 1972, who proposes that the difference stems from alternate realizations of the null 'exp' (ekspektativnost) predicate da bude ('may it be') with infinitives and $d a+$ present. A similar type of semantic factor is explored in Gudkov 1958, who notes the condition of 'getting closer to a result' with $d a+$ present. Katičić's (1986) syntactic account of the distinction includes infinitivization' transformation, whereby the infinitival complement loses its predicational features being integrated in the matrix predicate.

In formal, generative linguistics literature, the syntactic and semantic nature of $d a+$ present structures has attracted a lot of attention (cf. Todorović, 2012; Todorović \& Wurmbrand, 2015, a.o.). However, these accounts have relatively little to say about infinitives, even though the two structures are often in virtually free variation for many speakers, as often pointed out in the literature on the topic. ${ }^{5}$

${ }^{4}$ Similar proposals can be found in Moskovljević, 1936 and Brozović, 1953, who also attribute the difference to the type of subject, albeit without any predictive power.

5 The issue of whether the variation is indeed free from the linguistic standpoint is not settled in the literature. Piper et al. (2005: 324-328), for example, state that the distribution can be 'facultative' (with both options equally or freely available) and 'complementary' (where only one form is allowed). The authors, however, remain rather neutral with regard to what 'primary' and 'secondary' uses (where available) of one or the other non-finite form actually entail. 
An account of $d a+$ present should then explain the potential variation with infinitives and vice versa. Author 1 and Author 2 (to appear) suggest that because of their potential interchangeability, these could be underlyingly (roughly) the same structures, as in (2).

(2)

pojesti supu

eat.INF soup.ACC

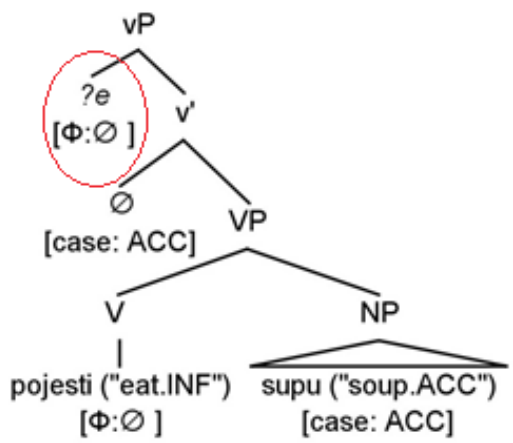

da pojedem supu

DA eat.1S.pres soup.ACC

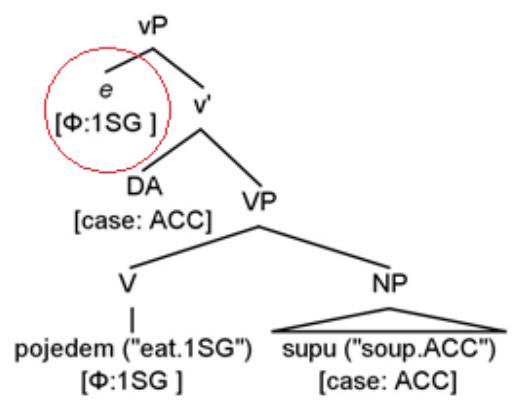

While both $d a+$ present and infinitives are structurally vPs, the difference is in the way the phi features on the verbal head ( $\left.\mathrm{v}^{\circ}\right)$ are valued. With $d a+$ present, v's phi features are valued by the subject in Spec vP, while with infinitives, the same set of features are valued as „Ø” and spelled out in the form of the infinitival suffix. The relevant difference in phi features could be captured by assuming that the $\mathrm{vP}$ spelled out as the infinitive does not project the Spec position.

If this is on the right track, then all the potential differences between $d a+$ present and infinitive will be related to the presence/absence of the subject in Spec vP.

\section{METHOD}

With research of free-like syntactic variation, both experimental and observational methods can run into problems. Our limited knowledge of the rules that determine which of the structures is preferred in which contexts prevents us from constructing the right conditions to elucidate one and exclude others. What we need is an exploratory study of empirical data that would give us a rough idea of 
what these rules are before we can formulate hypotheses and test them in a larger language sample.

To tackle the variation in the non-finite complements, we have opted for a controlled corpus study. In cases when linguistic phenomena under investigation are subject to seemingly free variation or variation governed by very subtle differences, we believe that the research method has to be highly constrained in order to abstract away from as many confounding factors as possible. For that reason, we have chosen to test the nature of the variation on a limited corpus of three literary translations. ${ }^{6}$ Several factors governed this particular choice. Firstly, written production is more constrained than speech production, as it often involves conscious interventions (cf. Liberman, 1992; Linnel, 2004, a.o.). Awareness of the need to conform to standard language is certainly one aspect of the 'editorial' process involved in written production. Secondly, translation production differs from more spontaneous written production in that the translator/native speaker is more careful in conveying the language content and the communicative message (text analysis is an essential component in translation, cf. Wills, 1996; Nord, 1997). ${ }^{7}$ Thirdly, we have chosen to further limit the corpus and include written production/translation by a single native speaker. While this move constrains our findings to intra-speaker variation, it relieves us of the problem of possible interspeaker variation. Having in mind that the native speaker in question is a wellestablished translator, fully aware of the preferences of the standard variety of Serbian, choices of infinitives over $d a+$ present are more than likely to be wellmotivated. In addition, further analyses of the context and preferences in them have been done by the authors of the paper, all three native speakers of the Vojvodian variety of Serbian. ${ }^{8}$ Future research will show if the factors uncovered in this study

\footnotetext{
${ }^{6}$ The corpus includes three literary translations from English into Serbian, Winter Journal by Paul Auster, Can't and Won't by Lydia Davis, and Shooting Angels by Christopher Hope, translated into Serbian as Zimski dnevnik, Ne mogu i neću, and Lov na anđele, respectively, by Ivana Đurić Paunović.

${ }^{7}$ Even though translation corpora are often used for contrastive linguistic analyses, this method is not very common in theoretical work, where data based on introspection or more spontaneous language production is preferred. We believe this 'compromise' is needed in this case.

${ }^{8}$ Even though neither $d a+$ present nor infinitive are excluded from the end-points of the Serbian/Croatian dialect continuum, it has been noted that the use of infinitive progresses westward (cf. Ivić, 1972; Piper et al., 2005 and references there). It is plausible then that the
} 
can be extended to hold for the variation at the inter-speaker level or how consistently they underlie variable performance of other individual speakers. In other words, before we can measure out the variation, we first need to understand its nature. Studying the performance of an idealized (single) native speaker for this purpose seems to be a reasonable starting point.

\section{FINDINGS}

\section{Stylistics: avoid repetition}

As has been pointed out in the literature (cf. Ivić, 1972: 128; Piper et al., 2005: 325, a.o.), the reasons for the preference of infinitive over $d a+$ present can be purely stylistic - to avoid repetition. There are a number of contexts in which the $d a$ particle found in $d a+$ present structures can be virtually stacked. Namely, as is quite commonly assumed in the syntactic literature, there are at least three different kinds of $d a$ in Serbian (Todorović, 2012). Da can appear as a complementizer, a subjunctive marker, and the 'lowest' vP internal $d a$, the one of interest in this paper (cf. Todorović and Wurmbrand, 2015; Author 1 and Author 2, to appear).

In our translation corpus, infinitives are often used to avoid the repetition of $d a$. Using the infinitives after the modal verbs morati 'must' in (3), the number of instances of $d a$ has been reduced from (potential) six to four. $\begin{array}{llllllll}\text { (3) Zaboravljamo, } & \text { za sada, } & \text { da } & \text { moramo paziti } & \text { da } & \text { se } & \text { ne } & \text { izgubimo } \\ \text { forget.1P } & \text { for now } & \text { DA, i } & \text { must.1P take-care.INF } & \text { DA } & \text { SE } & \text { not } & \text { get-lost }\end{array}$

da moramo znati da se vratimo do ulaska u tunel and DA must.1P know how to SE return to entrance in Tunnel 'We forget, for now, that we must be careful not to get lost, but must find our way back to the mouth of the tunnel'

(Can't and Won't: 218)

Instances such as (3) strongly indicate that whatever differences might underlie $d a+$ present as opposed to infinitive, they must be subtle enough to be suppressed by stylistic considerations.

native speakers in Vojvodina could employ more infinitives in their production than other speakers of Serbian. 


\section{Impersonal contexts}

The use of infinitives in impersonal contexts corroborates the observations in the literature (cf. Belić, 2005; Piper et al., 2005) that impersonal predicates show a noticeable preference for infinitives. This is especially true for the impersonal modal verb trebati ('need') with non-referential subjects in the complement (4).

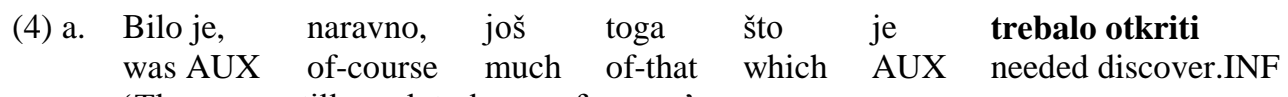
'There was still much to learn, of course'

(Winter Journal: 50)

$\begin{array}{llllll}\text { b. } & \text { Trebalo bi upotrebiti } & \text { nešto } & \text { nalik } & \text { kvantnoj } & \text { teoriji } \\ \text { needed AUX use.INF } & \text { something like } & \text { quantum } & \text { theory } \\ \text { 'You needed to go to something like quantum theory' } & & \end{array}$

(Shooting Angels: 16)

In standard Serbian, the impersonal trebati 'need' with complements containing a referential subject requires $d a+$ present (cf. also Ivić, 1972: 123).

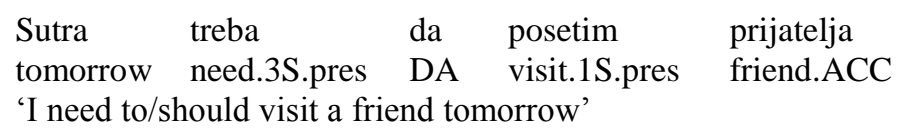

$D a+$ present, however, is not incompatible with impersonal interpretation, as it can be impersonalized by the reflexive particle SE (whose purpose is to suppress the agent theta role and render the meaning impersonal, cf. Marelj, 2004, a.o.). Still, impersonalized $d a+$ present is the dispreferred option (6b).

$\begin{array}{llll}\text { (6) a. Sutra } & \text { treba } & \text { pokositi travnjak } \\ \text { tomorrow need.3S.pres mow.INF lawn.ACC } & \text { mown the lawn tomorrow' }\end{array}$

$\begin{array}{llllll}\text { b. } & \text { ?Sutra treba } & \text { da } & \text { se } & \text { pokosi } & \text { travnjak } \\ \text { tomorrow need.3S.pres } & \text { DA } & \text { SE } & \text { mow.INF } & \text { lawn.NOM } \\ \text { 'Someone should mow the lawn tomorrow' } & & \end{array}$

Note that the particle SE is not needed with the infinitive (6a). It seems that SE yields impersonalization that includes the participants in the conversation, 
while the infinitive is simply unspecified for the external theta role, and is therefore viewed as 'more impersonal' in this context.'

\section{Inanimate antecedents of the null subject}

Another factor that made the appearance of the infinitive as the complement of a modal verb more likely was animacy, as the use of infinitives was often licensed by inanimate subjects. This effect is illustrated in the examples in (7), where both subjects are inanimate and abstract.

(7) a. najčudovišnija smrt iz tebe nije mogla izvući ni jednu jedinu suzu most-monstrous death from you not-AUX could get.INF not one single tear 'monstrous death could not could coax a single tear from you'

(Winter Journal: 130)

b. Spasenje nam može doneti samo neodoljiva milost salvation us can bring.INF only irresistible grace

'We can be saved only by irresistible grace'

(Shooting Angels: 156)

If the condition observed here proves to operate across-the-board, this would mean that $d a+$ present prefers its external theta role to be agentive/volitional.

\section{Non-referential antecedents}

The next factor that was associated with the choice of infinitives was referentiality of the antecedent. In (8a), the subject of the modal construction is the noun čovek ('man') with generic reference, and in ( $8 \mathrm{~b})$ it is a universally-quantified noun phrase svaki prolaznik ('every passer-by') with universal reference.

(8) a. Koliko blizu čovek može prići rubu života, a da ne padne? how close man can approach.INF edge of-life and DA not fall-off 'How close might you get to the edge of life without falling off?'

(Shooting Angels: 68)

\footnotetext{
${ }^{9}$ Piper et al (2005: 470) state that infinitive is the most neutral way to name/express a verbal action (cf. also Ajdžanović \& Dražić, 2016: 23). It is unclear though how this insight can be formalized, as (verbal) nouns can do the same. What seems to be assumed here is a correlation between finiteness (and possibly case) and argument structure, which is both empirically and theoretically problematic.
} 
b. prislonio sam novčanice uz staklo tako da ih svaki prolaznik može videti I-pushed AUX notes against glass so that them every passer-by can see.INF 'I pushed the notes up against the pane for any passer-by to see...'

(Shooting Angels: 20)

In both cases, the fact that the subject does not refer to a unique individual or a set of individuals seems to license the use of infinitives.

\section{Impersonal modals and stative complements}

In contrast to the modal verb trebati, which is impersonal by default, other modals like moci ('can') and morati ('must') require agreement and hence a potentially syntactically-active subject (9). ${ }^{10}$

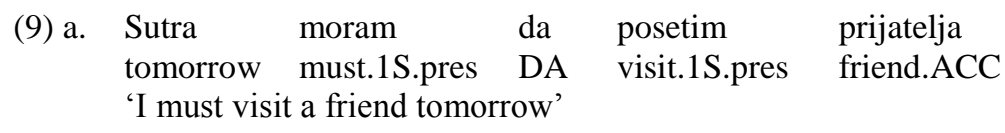
b. *Sutra mora
tomorrow must.3S.pres
'I must visit a friend tomorrow'
da posetim
DA visit.1S.pres
prijatelja
friend.ACC

Modal verbs morati and moći can be impersonalized using the SE morpheme (10a). It should be noted that the infinitive is used as the complement of the modal once the modal is impersonalized (da+present is not acceptable (10a'). The impersonalization can also be carried out by adding SE to the lexical verb, in which case the modal receives a default agreement suffix. Impersonalized $d a+$ present (10b') is out in this case (cf. also Stevanović, 1954 and Ivić, 1972).
(10) a. Sutra
se mora
posetiti prijatelj
tomorrow SE must.3S.pres visit.INF friend.NOM
'A friend has to be visited tomorrow'
a'. *Sutra se mora da poseti prijatelj tomorrow SE must.3S.pres DA visit.3S.pres friend.NOM 'A friend has to be visited tomorrow'

\footnotetext{
${ }^{10}$ Default agreement found on the impersonal trebati 'need' must then be viewed as operating in a different fashion.
} 

b. Sutra mora da se poseti prijatelj tomorrow must.3S.pres DA SE visit.3S.pres friend.NOM 'A friend has to be visited tomorrow'
b'. *Sutra se mora da se poseti prijatelj tomorrow SE must.3S.pres DA SE visit.3S.pres friend.NOM 'A friend has to be visited tomorrow'

We also noticed that if the lexical verb is stative, as in (11), there is a tendency to impersonlize the modal verb using the SE morpheme, and once this is done, the infinitival form of the lexical verb becomes highly preferred.

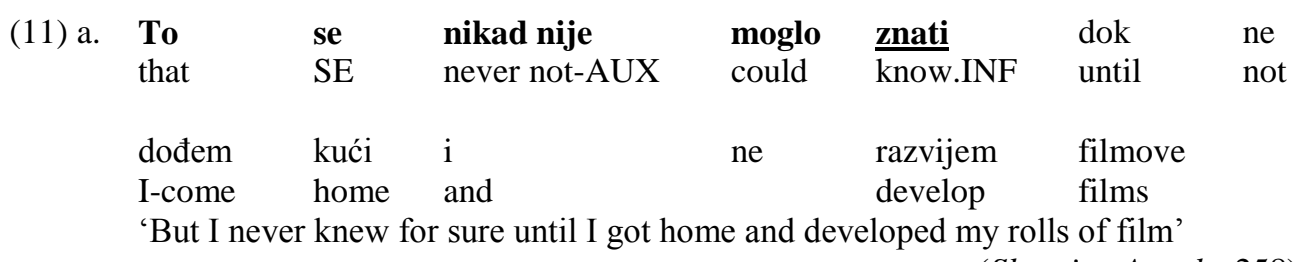

(Shooting Angels: 258)

b. Ono snage što je $u$ njoj ostalo potrošila je na

that strength that AUX in her left she-spent AUX on

bes, dementnu ljutnju zbog koje se nije mogla prepoznati

anger demented rage because of- SE not could recognize.INF

which

'Whatever strength was left in her she spent on anger, demented rage that made her unrecognizable'

(Winter Journal: 191)

The alternatives to the examples in (11) containing $d a+$ present instead of infinitives would be sentences in (12).

(12) a. To nikad nije moglo da se zna ...

that never not-AUX could DA SE know.3S.pres

$\begin{array}{llllll}\text { b. ... zbog kojih } & \text { nije } & \text { mogla da } & \text { se } & \text { prepozna ... } \\ & \text { because of-which not-AUX } & \text { could } & \text { DA } & \text { SE } & \text { recognize.3S.pres }\end{array}$

The examples in (12), however, would appear highly marked in the given context. Additionally, the alternative interpretation that arises (with certain verbs) is a reflexive one. (12b) could, thus, be interpreted as saying that she [the subject] was not able to recognize herself. 


\section{Deontic vs. epistemic modality}

The last factor identified was the difference between epistemic and deontic modality. In (13), we have a sentence with an epistemic modal reading, and the infinitive, rather than $d a+$ present.

$\begin{array}{llllll}\text { (13) } \begin{array}{llll}\text { Znam } \\ \text { I-know }\end{array} & \begin{array}{l}\text { kako } \\ \text { how }\end{array} & \begin{array}{l}\text { je } \\ \text { AUX }\end{array} & \begin{array}{l}\text { to } \\ \text { that }\end{array} & \begin{array}{l}\text { moralo } \\ \text { must }\end{array} & \begin{array}{l}\text { izgledati } \\ \text { look.INF }\end{array} \\ \begin{array}{l}\text { kasno } \\ \text { late }\end{array} & \begin{array}{l}\text { uveče, } \\ \text { evening }\end{array} & \begin{array}{l}\text { mislila } \\ \text { she- thought }\end{array} & \begin{array}{l}\text { je } \\ \text { AUX }\end{array} & \begin{array}{l}\text { na } \\ \text { on }\end{array} & \begin{array}{l}\text { mene } \\ \text { me }\end{array} \\ \text { 'I know how it must have been-late in the evening, she was thinking of me' }\end{array}$

(Can't and Won't: 154)

The choices of infinitives as complements of epistemic modals were quite systematic. Based on this observation, as well as our own intuitions, we hypothesize that infinitives are preferred in the complements of epistemic modals.

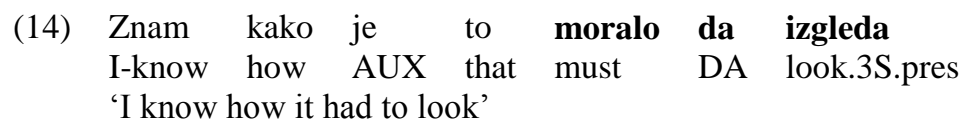

(14) shows the equivalent of (13) with $d a+$ present, and according to our intuitions, the only possible reading is the deontic one.

\section{DISCUSSION}

The empirical data from our study confirms that infinitives are a more likely choice in impersonal constructions, as pointed out in the literature. Some novel insights include the nature of the subject. When modal constructions have a non-referential, inanimate subject or non-agentive subject, infinitives are more likely to appear. Moreover, epistemic modal constructions appear to be better formed if they contain an infinitive and they sound degraded with $d a+$ present.

These differences between infinitives and $d a+$ present are systematic and interconnected enough to motivate a search for a unified account. The question that needs to be answered is why at least some speakers prefer infinitives over $d a+$ present constructions in epistemic modality contexts and when the subject is non-referential, non-agentive or inanimate. Author 1 and Author 2 (to appear) argue that infinitives might be different from $d a+$ present in that they do not project a Spec vP position, as illustrated in (2), repeated here as (15). 
(15)

pojesti supu

eat.INF soup.ACC

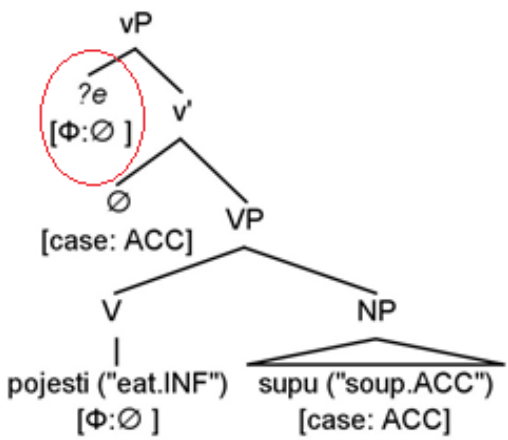

da pojedem supu

DA eat.1S.pres soup.ACC

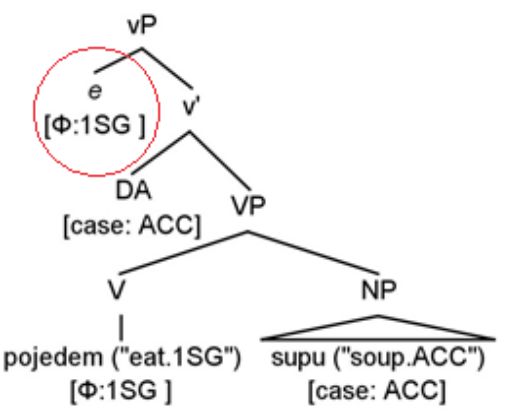

The sensitivity of $d a+$ present complements to the type of null subject referent supports the proposal that the difference between infinitives and $d a+$ present is in terms of Spec vP. Descriptively, there seems to be a correlation between a syntactically present null external argument and its interpretation. The effect of 'discourse participant inclusion', as well as the interference of the reflexive interpretation in intended impersonal contexts with $d a+$ present suggests that the syntactically present null element is more difficult to suppress; it is semantically active, and the speakers rather interpret it either non-generically or even as the binder of the reflexive SE. This effect seems to be completely absent with infinitives, and it appears that the interpretation of the null external argument of the infinitive is more easily obtained in relation to the properties of the matrix verb. These differences cannot be formalized before we fully understand the nature of syntactically and semantically present null elements. ${ }^{11}$

The other question that arises is what connects the difference between epistemic and deontic modality to the structural discrepancies concerning the subject position. A possible direction for further research here is von Fintel and Iatridou's (2003) suggestion that complements of epistemic and deontic modals are different in the kind of subject they contain, so that epistemic modals disallow

\footnotetext{
${ }^{11}$ In principle, the null element could be the result of raising (trace, copy) or a kind of PRO, if one assumes that these are control structures (cf. Wurmbrand, 2001, a.o.).
} 
variable binding from the outside, which renders scopal ambiguities unavailable with them, as opposed to deontic modals.

\section{CONCLUSION}

In conclusion, we have provided further evidence that variation in the form of modal complements in Serbian is not completely free. Slight differences in the syntactic behavior of $d a+$ present and infinitive complements found in the translation corpus have been then taken to motivate the claim that they differ in terms of the kind of subject that they have. Specifically, non-referential, inanimate subjects, impersonal and epistemic modal constructions have been linked to the greater likelihood of infinitives. This link has been accounted for by assuming a structural difference in terms of the presence/absence of the external argument position in syntax (Spec vP).

We have managed to highlight only a small fraction of possible factors influencing the choice of one form over the other. The fact remains that outside the limited set of contexts identified here, the variation is still mysterious. If we maintain that the syntactic presence of a null subject in the structure differentiates $d a+$ present from infinitives, subtle interpretational differences are expected with referential subjects as well. What point of modal meaning will be affected and to what extent can only be uncovered after a careful investigation.

Peđa Kovačević, Tanja Milićev, Ivana Đurić Paunović

VARIJACIJA U NELIČNIM DOPUNAMA U SRPSKOM JEZIKU: EMPIRIJSKI NALAZI NA NIVOU JEDNOG GOVORNIKA

\section{Rezime}

Rad se bavi istraživanjem faktora koji čine odabir infinitiva kao dopune modalnih glagola prihvatljivijim u odnosu na $d a+$ prezent na ograničenom korpusu tri književna prevoda, kao i načinom sintaksičke reprezentacije varijabilinih struktura. Uz pomoć analize konteksta, potvrđuju se dosadašnja opažanja iz literature da se infinitiv pojavljuje umesto $d a+$ prezenta zbog stilističkih razloga (izbegavanje ponavljanja partikule $d a$ ), kao i da je infinitiv češći u impersonalnin kontekstima. Novi doprinos ovog istraživanja čini ukazivanje na kontekste $u$ kojima je subjekat neživ, apstraktan, nereferencijalan i neagentivan, kao i konteksti epistemičke nasuprot deontičkoj modalnosti u kojima je infinitiv prihvatljiviji, ako ne i obavezan. Kako se svi ovi faktori mogu povezati s prirodom (nultog) subjekta dopune, objašnjenje ovih razlika može se tražiti na nivou argumentacijske strukture - vP-a ili proširenog vP domena. Uvidi stečeni na osnovu varijacije unutar jednog govornika, na 
kontrolisanom korpusu, predstavljaju dobru polaznu tačku za dalje istraživanje ovih i dodatnih faktora kod/ među drugim govornicima.

Ključne reči: nelične dopune, $d a+$ prezent, infinitiv, sintaksička varijacija, analiza prevoda

\section{REFERENCES}

Ajdžanović, J. - Dražić, J. (2016). Sintaksičko-semantička analiza konstrukcije za + infinitiv i

njene pragmatičke implikacije. Godišnjak Filozofskog fakulteta u Novom Sadu, XLI-1, 21-31.

Auster, P. (2012). Winter Journal. New York: Faber and Faber.

Brozović, D. (1953). O razlikama između infinitiva i prezenta s veznikom da. Jezik; časopis za kulturu hrvatskoga književnog jezika, 2/5, 153-154.

Davis, L. (2014). Can't and Won't. London: Penguin Books.

Dejvis, L. (2015). Ne mogu i neću. Beograd: Geopoetika. Prevod: Ivana Đurić Paunović.

Fintel, Von K. - Iatridou, S. (2003). Epistemic containment. Linguistic Inquiry, 34(2), 173-198.

Gallis, A. (1970). Zum Gebrauch von DA+Präsens versus Infinitiv beim Futurum I in Serbokroatischen: Untersuchungen über die 'Koreni' von Dobrica Ćosić. Zbornik Matice srpske za filologiju i lingvistiku, 13/2, 217-223.

Gudkov, V. Р. (1958). Употребление инфинитива и конструкции с да в сербском языке (сочетания с глаголами). Bопросы лингвистики и методики преподавания иностранных языков, 6, 98-112.

Hope, C. (2011). Shooting Angels. London: Atlantic Books.

Houp, K. (2013). Lov na anđele. Beograd: Geopoetika. Prevod: Zoran Paunović i Ivana Đurić Paunović.

Huddican, B. \& Plunkett, B. (eds.) (2010). Formalizing syntactic variability. Lingua (Special Issue), 120/5, 1057-1332.

Ivić, M. 1970. O upotrebi glagolskih vremena u zavisnoj rečenici: prezent u rečenici s veznikom da. Zbornik Matice srpske za filologiju i lingvistiku, 13/1, 4355.

Ivić, M. 1972. Problematika srpskohrvatskog infinitiva. Zbornik Matice srpske za filologiju i lingvistiku. 15/2, 115-138.

Katičić, R. (1986). Sintaksa hrvatskoga književnog jezika. nacrt za gramatiku. Zagreb: HAZU.

Klajn, I. (2005). Gramatika srpskog jezika. Beograd: Zavod za udžbenike i nastavna sredstva. 
Kovačević, P. - Milićev, T. (to appear). The nature(s) of syntactic variation: Evidence from the Serbian/Croatian dialect continuum. Paper submitted to Proceedings of Formal Description of Slavic Languages 12, Berlin, 2016.

Libermann, A. (1992). The relation of speech to reading and writing. Advances in Psychology 94,167-178.

Linnel, P. (2004). The Written Language Bias in Linguistics. London/New York: Routledge.

Oster, P. (2012). Zimski dnevnik. Beograd: Geopoetika. Prevod: Ivana Đurić Paunović.

Piper, P. - Antonić, I. - Ružić, V. - Tanasić, S. - Popović, L. \& Tošović, B. (2005). Sintaksa savremenog srpskog jezika: prosta rečenica. Beograd: Institut za srpski jezik SANU.

Marelj, M. (2004). Middles and Argument Structure across Languages. PhD dissertation, Netherlands Graduate School of Linguistics.

Moskovljević, M. S. (1936). Još o upotrebi svezice „da” s prezentom mesto infinitiva. Naš jezik, 4, 106-113.

Nord, C (1997). Translation as a Purposeful Activity: Functionalist Approaches Explained. Manchester: St. Jerome.

Stevanović, M. 1954. Naporedna upotreba infinitiva i prezenta sa svezicom da. Naš jezik (nova serija), 5/3-4, 85-102 \& 5/5-6, 165-185.

Todorović, N. (2012). The Indicative and Subjunctive da-Complements in Serbian A Syntactic-Semantic Approach. PhD dissertation, University of Illinois.

Todorović, N. - Wurmbrand, S. (2015). (In)Finite possibilities of 'da': Restructuring the tense and aspect domains. Workshop on aspect in embedded clauses, ZAS, Göttingen. Preuzeto sa http://wurmbrand.uconn. edu/Resources/da\%20da\%20da\%20HO.pdf

Wilss, W. (1996). Knowledge and Skills in Translator Behaviour. Amsterdam: John Benjamins.

Wurmbrand, S. (2001). Infinitives: Restructuring and Clause structure. Berlin: Mouton de Gruyter. 